\title{
Олег Іванюк
}

\section{ПЕРЕДУМОВИ ПРОВЕДЕННЯ ЗАГАЛЬНОГО ПЕРЕПИСУ 1897 р. В НАДДНІПРЯНСЬКІЙ УКРАЇНІ Й ПОТРЕБИ У ВИЗНАЧЕННІ ЕТНІЧНОГО СКЛАДУ НАСЕЛЕННЯ}

У статmі проаналізовано державну етнополітику Російської імперії у XIX cm. Визначено, що ії головним стрижнем стала лояльність підданих до держави та правлячої династії. Розглянуто основні передумови підготовки і проведення загальноросійського перепису населення 1897 р. у контексті генези питання щодо необхідності визначення етнічного складу жителів імперії. З'ясовано, що упродовж XIX cm. з метою упорядкування або обмеження прав національних меншин було видано низку законодавчих актів, що у свою чергу призвело до значних переміщень населення і перетворення міст України на багатоначіональні адміністративні осередки. Узв'язку з необхідністю контролю за рухом населення, яке належало до різних етнічних груп, і під впливом іноземних країн правлячі верстви Росії прийшли до усвідомлення потреби детального обліку населення загалом і його етнічного складу зокрема.

Ключові слова: перепис, етнічний склад, начіональна політика, етнічна група, національна меншина, іноземні переселенці.

У другій половині XIX ст. самодержавна Росія в ході політичної і військової експансії сформувала сталі кордони. До складу імперії входили території Балтії, Фінляндії, частина Польщі, Білорусії, землі України, Сибіру, Далекого Сходу, Кавказу, Казахстану і Середньої Азії. Специфічний державний механізм управління дозволяв керувати багатонаціональною країною, народи якої перебували на різних рівнях економічного, соціального та культурного розвитку.

Наприкінці XVIII ст. в українських землях почали запроваджувати адміністративні, правові, соціальні відносини, притаманні іншим частинам імперії. Рівночасно з поступовим становленням імперської системи управління упродовж XIX ст. владу почали цікавити питання, пов'язані із етнічним складом населення.

Дослідження історії національних меншин в Україні розпочалися ще у 50-60-ті роки XIX ст. У працях П. Кеппена систематизовано матеріали про етнічний склад населення європейської частини Російської імперії [22]. У 1863 р. видано працю О. Ріттіха, яка містила розпис етнічного складу населення по губерніях [35]. Перші наукові праці, присвячені підготовці та проведенню загальноросійського перепису населення 1897 р., з'явилися одразу після його завершення. Науковий інтерес викликало дослідження відомого статистика А. Котельникова, що критично відображало потреби й певні аспекти цієї статистичної операції [24]. У книзі Б. Кадомцева розглядається соціальний та професійний склад населення європейської частини Росії у 1897 р. та його відображення в переписній операції [20]. Спираючись на аналіз матеріалів загальноросійського перепису населення 1897 р., багато дослідників вивчали етнічні процеси в Україні. Міграційні процеси, заснування міст, формування етнічної структури населення відображені у працях Д. Багалія, А. Шмідта, П. Чубинського, Є. Крижановского [2; 43; 42; 25] та ін.

С. Громачевський проаналізував вплив обмежувальних законів про землеволодіння польського дворянства на зміни чисельності польського населення Правобережжя України у другій половині XIX ст. [14]. А. Ярошевич визначив етнічний склад населення, насамперед чисельність та розселення українців [45].

За доби незалежності України дослідження національних меншин загалом і етнічного складу населення окремих регіонів значно активізувалися. Матеріали щодо загальної чисельності окремих етнічних груп та їх кількості в окремих регіонах і містах, зібрані переписом, аналізувалися I. Лісевичем [26], О. Буравським (польські вчені) [4] та ін. Перепис 1897 р. досліджували сучасні російських науковці М. Григорянц, Ф. Зав'ялов $[13 ; 15]$. В.В. Малий розглянув демографію корінного населення Поділля, а саме українців, наприкінці ХIX ст. [27].

Метою дослідження $€$ аналіз передумов проведення загальноросійського перепису населення 1897 р. в українських губерніях й визначення потреб у фіксації етнічного складу жителів імперії. Відповідно до мети сформульовано такі дослідницькі завдання: висвітлити державну політику 
щодо національних меншин в Україні, проаналізувати імперське обмежувальне законодавство, окреслити процес підготовки до проведення загальноросійського перепису населення 1897 р., проаналізувати генезу питання визначення етнічної приналежності жителів імперії у переписних формах обліку населення.

Головним стрижнем державної етнополітики Російської імперії у XIX ст. стала лояльність підданих щодо держави та правлячої династії. Пріоритетами для центру виступали безпека влади і соціально-політична стабільність. Наприклад, більшість поляків і євреїв вважалися ненадійними підданими, у той час як до прибалтійських німців, фінів та вірменів до середини XIX ст. ставилися як до вірних слуг царя. Нижній щабель імперської етнічної ієрархії займали етнічні групи, які залежали від еліт інших народів. У Російській імперії до цієї категорії належали естонці, латиші, литовці, білоруси й українці, які до поділів перебували у складі Речі Посполитої. Це призвело до того, що імперський центр тривалий час поєднував естонців і латишів із прибалтійськими німцями, а литовців, білорусів і правобережних українців - із поляками. У такий спосіб у XIX ст. в очах росіян маси українців стали «хохлами», прототипом нецивілізованого селянина. Вони перестали бути безпосереднім об'єктом царської політики і сприймалися у Правобережній Україні як функція домінантної у регіоні польської або відповідно російської чи русифікованої еліти в Лівобережжі й на Півдні.

Разом $з$ тим держава прагнула асимілювати «ненадійні» національні меншини і створити єдиний «русский народ». Упродовж XIX ст. $з$ метою упорядкування або обмеження прав національних меншин було видано низку законодавчих актів, що в свою чергу призвело до значних переміщень населення і перетворення міст України на багатонаціональні адміністративні осередки. У цей період виник і закріпився етнонім «русские», який у державному розуміння включав до свого змісту назви трьох народів великоросів, малоросів (українців), білорусів. Водночас синонімом поняття «русский» було поняття «православний». Тому католики або протестанти, які прийняли православ'я, вважалися державою «русскими». Так само, наприклад, синонімами вважалися поняття «поляк» і «католик». Термін «національні меншини» не був офіційно впроваджений і не застосовувався у законодавчих актах та інших документах.

Органи державної влади, наприклад Міністерство внутрішніх справ, зазначали, що майже усі іновірці були приєднані до імперії шляхом завоювань і не належали до російського народу, а тому в їхньому середовищі спостерігалися стійкі сепаратистські настрої, які не збігалися з прагненнями імперії [21, 198]. Духовні лідери інших віровизнань, на думку влади, переслідували політичні цілі й боролися проти панівної церкви, яка була однією з підвалин імператорської влади. Тому основним завданням держави визначалося недопущення поширення будь-яких релігійних течій, окрім православ'я. Зростання кількості «іновірців» вважалося можливим лише за рахунок природного приросту або подальших територіальних приєднань [21, 199]. Держава наголошувала на необхідності насадження й розвитку на окраїнах початків російського державного устрою, російської школи, надання російській мові «приличествующего значения» в усіх громадських місцях й установах i «слияние окраин с коренной Россией и укрепление сим государственного единства» [21, 200]. Заходами щодо реалізації окреслених завдань стало запровадження Міністерством внутрішніх справ російської мови у листування іншоконфесійних установ, “ї обов'язкове вивчення у духовних навчальних закладах, мовний ценз для магометанського духовенства, підпорядкування Міністерству народної освіти усіх шкіл, які працювали «при иноверческих церквях» [21, 200]. Римо-католицькому духовенству було заборонено відкривати школи. Встановлювався нагляд за тими поляками, які намагалися навчати дітей грамоти польською мовою. Заборонялися друк, читання й розповсюдження польських книг і газет, спілкування з польськими емігрантами за кордоном $[4,38]$. Судового переслідування зазнавали поляки, які публічно співали пісень рідною мовою або носили національний одяг $[4,38]$. 23 січня 1885 р. Міністерство внутрішніх справ отримало дозвіл царя на закриття на Правобережній Україні римо-католицьких монастирів та зведення їх кількості до підконтрольної місцевій адміністрації [21, 207].

Бажання асимілювати «ненадійних» підданих знайшло відображення у політиці державного антисемітизму, що призвело до зосередження євреїв у межах міст і містечок. Упродовж XIX ст. було видано низку указів, які обмежували права цієї національної меншини. Царський указ від 9 грудня 1804 р. визначав статус євреїв і регламентував умови їх проживання у межах України $[9,731-737]$. За положеннями документу вони визнавалися належними до міського населення і зобов'язувалися упродовж трьох-чотирьох років залишити сільськогосподарські райони $[31,9]$. Указ також обмежував містами й містечками територію, де євреї мали право здійснювати торговельні операції. Їм заборонялося займатися шинкарством та орендувати помістя.

У 1827 р. за «височайшим велінням» євреїв було виселено з Києва, а 20 листопада 1829 р. з Миколаєва та Севастополя [16]. За іменним указом Миколи від 30 травня 1835 р. підтверджено існування започаткованої указом імператриці 
Катерини II від 23 грудня 1791 р. «смуги осілості» єврейського населення [17]. До неї увійшли Волинська, Подільська, Катеринославська, Київська (за винятком Києва), Херсонська (окрім Миколаєва), Таврійська (окрім Севастополя), Чернігівська губернії $[33,125]$. Метою цієї акції було зосередження євреїв на національних окраїнах Російської імперії [10]. Це призвело до їх штучної скупченості у містах. Значна кількість євреїв, об'єднана в кагали, проживала в Одесі, Херсоні, Катеринославі, Судаку, Керчі. Переважна їх більшість зосереджувалася у губернських, повітових центрах і промислово розвинутих містах Лівобережної України.

Положенням від 30 травня 1835 р. Комітет міністрів та цар Микола I затвердили дозвіл на постійне проживання євреїв у будь-якій місцевості Правобережної України, крім м. Київ. А вже через рік новий закон ввів обов'язкову реєстрацію євреями своїх прізвищ, що дозволяло встановити контроль за переміщенням осіб, належних до цього народу $[12,11]$.

У 1844 р. указом Миколи I запроваджено податки на традиційний єврейський одяг, на придбання лампадок для синагог, було знищено кагали. Євреї підпорядковувалися загальним органам міського самоврядування [11]. У 1850 р. було заборонено носити традиційний єврейський одяг взагалі. 31857 р. євреї отримали паспорти, які діяли лише у місцях їхнього проживання $[38,114]$.

У 60-х роках XIX ст. правове становище євреїв дещо поліпшилося. 2 грудня 1861 р. Державна рада дозволила проживати в Києві купцям першої та другої гільдій єврейської національності [29]. Згодом дозволялося жити євреям: купцям першої гільдії, які належали до неї упродовж п'яти років і не перебували під судом та слідством, разом 3 ними на нове місце могли переїхати один прикажчик та чотири особи прислуги на одну родину; особам, які отримали вищу освіту за професіями дантист, аптекар, фельдшер; ремісникам, якщо у них було наявне цехове свідоцтво. Але приїхавши до Києва, вони не могли змінювати фах або додатково займатися іншими видами діяльності.

Євреям заборонялося орендувати винокурні та питейні заклади, працювати у галузі іконопису, укладати шлюб з представниками інших етносів.

$\mathrm{Ti}$, хто належав до перелічених вище категорій, мали право на проживання у Либідській та Плоскій частинах Києва. В інших районах міста євреї могли мешкати тимчасово і тільки з дозволу місцевої влади. Загалом поза «смугою осілості» допускалося перебування євреїв упродовж шести тижнів. Губернське правління у разі потреби мало право продовжити цей термін ще на два місяці. Дозвіл давали лише за обставин успадкування власності, розгляду справ у судових чи урядових органах, здійснення торгових операцій $з$ метою забезпечення товарами міст та містечок, що входили до «смуги осілості», участі у ярмарках.

У другій половині XIX ст. євреї домоглися поступового розширення прав. Вони здобули: право отримувати державні нагороди (1858р.), право на торгівлю алкоголем (1863р.), право реєстрації винокурних заводів на власне ім'я (1868р.). Але водночас зберігалися і заборони. Так, у 1864 р. була підтверджена заборона на придбання земельних ділянок у межах Київського генерал-губернаторства. Урядові «Правила», видані 3 травня 1882 р., забороняли євреям селитися поза межами міст та містечок [7]. У прикордонних губерніях їм не дозволялося проживати у п’ятдесятикілометровій смузі вздовж кордону. Влада заборонила будь-які угоди стосовно купівлі землі, а також оренду нерухомості поза межами міст і містечок $[37,190]$.

У 1887 р. встановлено норму для вступу євреїв до навчальних закладів. Їм заборонялося вчитися в університетах губернських міст. У Києві до середніх навчальних закладів дозволяли приймати не більше 5 \% євреїв від загальної кількості тих, хто навчався, до вищих - не більше 3 \% $[41,163]$.

У прагненні інкорпорувати Правобережну Україну, яка увійшла до складу імперії у 90-ті роки XVIII ст., царський уряд зіткнувся 3 проблемою домінування поляків-землевласників у системі земельної власності та поляків-службовців у системі управління краю. Нейтралізація польського впливу стала центральною проблемою царату. Вона зумовлювала особливості більшості адміністративно-управлінських заходів. Після поразки польського повстання 1863 р. російський уряд не лише репресував причетних до революційних подій, але й шляхом конфіскації земельної власності та санкціонованого іноземного переселення намагався послабити вплив поляків на економічне та політичне життя регіону, створити нейтральне, а то й вороже для поляків середовище, де ідеї відновлення незалежної Польщі не знайшли 6 відгуку [3, 17]. У січні 1864 р. було запроваджено податок у розмірі $10 \%$ від річного прибутку землеволодіння на покриття видатків 3 утримання полонених поляків, їхню депортацію, заробітну платню судових військових комісій, збільшення кількості православних церков. Цей захід мав наметі довести до банкрутства господарства, які належали польським землевласникам, передати їх росіянам і витіснити поляків із сільськогосподарського сектора $[3,23]$.

Кроком щодо послаблення польського впливу стало ініційоване імперією іноземне заселення Правобережної України. 10 липня 1870 р. імператор затвердив постанову Комітету міністрів «... о водворении чехов на Волыни...» Відповідно до законодавчого акту, чехи мали право обирати російське громадянство, не подаючи свідоцтва 
про благонадійність, та отримували деякі пільги щодо військової служби [6]. Розвиток капіталістичних відносин в Україні у пореформений період спричинив появу серед міського населення чехів, які мали високу робітничу кваліфікацію. В основному це були техніки та залізничники. У 1875 р. лише у Волинській губернії налічувалося 2190 чеських родин $[23,100]$.

Кількість іноземних переселенців зростала з року в рік. У 1870-х роках загалом в Україні їхня чисельність, порівняно з 1860 р., збільшилася майже втричі. Лише на Волині у 1890 р. іноземців налічувалося 200924 осіб. Переважну більшість з них складали німці та чехи.

Такий стан справ мав би задовольнити Російську імперію. Але наявність «не російських людей», «іновірців» турбувала царську адміністрацію на місцях та певні урядові кола. Упродовж 80-90-х років XIX ст. була розроблена система заходів, спрямованих на припинення іноземного переселення до Правобережної України та обмеження впливу чехів і німців, насамперед на економічну сферу. Київський губернатор генералад’ютант А.М. Дондуков-Корсаков запропонував заборонити поселення на Волині німецьких емігрантів, які не прийняли російського підданства. Спонукати іноземців до прийняття останнього повинне було скасування статуту «колоніста» та всіх передбачених пільг.

27 грудня 1884 р. імператор затвердив правила придбання у власність та оренду сільськогосподарських земель у західних губерніях, включаючи Київську, Подільську та Волинську. Закон традиційно обмежував польське землеволодіння та можливість придбання нових земель поляками, а також створював передумови для припинення іноземної колонізації взагалі [19].

У 1885 р. цар ініціював створення спеціальної комісії для розробки системи заходів, які б обмежили переселення в межі Російської імпеpii. 14 березня 1887 р. було підписано правила про заборону іноземним громадянам володіти і користуватися землею у Правобережжі. За законом переселенці могли отримати власність лише за умови прийняття російського підданства [18]. На підставі закону від 8 жовтня 1887 р. усі іноземні школи на території південно-західних губерній імперії підпорядковувалися Міністерству народної освіти. Усі навчальні програми національних шкіл були перероблені за загальноросійським зразком. У німецьких школах запроваджено обов'язкове вивчення російської мови. Навіть богослужіння в німецьких колоніях мало здійснюватися лише російською мовою [5].

У примітках до закону 1887 р. іноземцям надавалося право селитись і працювати у містах. Успадкування земельних володінь дозволялось лише тоді, коли спадкоємець оселився в Україні до прийняття означеного закону. В усіх інших випадках претендент на спадок зобов'язувався упродовж трьох років з часу набуття ним прав на майно продати його російському підданому. Уразі невиконання цього правила за розпорядженням губернатора нерухоме майно продавалося на публічному аукціоні, а гроші, за винятком комісійних, передавались іноземцю. Угоди щодо набуття майнових прав, укладені іноземцями у встановленому порядку після прийняття цього закону, не могли бути поновлені або продовжені.

Закон 18 липня 1888 р. скасував привілейований статус іноземних поселенців і зрівняв їх у правах з місцевим населенням. Також запроваджувався інститут прописки [39]. Іноземці мали проживати лише там, де вони були зареєстровані. Поселенці, які не прийняли російського підданства, приписувались для відбуття повинностей до найближчих волостей і підпорядковувались місцевому волосному правлінню. Вони були позбавлені права голосу на волосних зборах. Виняток становили лише дворяни та особи, які вступили на державну службу або мали звання почесних громадян і були членами гільдій.

Після оприлюднення правил від 18 липня 1888 р. генерал-губернатор Київської, Подільської та Волинської губерній генерал-лейтенант О. Ігнатьєв видав наказ зробити детальний перепис іноземного населення в цих губерніях. Спеціальною постановою він забезпечив контроль за переміщенням іноземних переселенців. У ній зазначалося, що будь-яке ухилення колоністів від перепису та незаявлення про перехід на нове місце каралось штрафом до 500 руб. або арештом до трьох місяців. Цей указ вказує на суто політичну мотивацію здійснення обліку етнічного складу населення. Проведений за таких умов перепис подав такі показники наявності іноземних поселенців в Україні: у Волинській губернії - 200924 осіб, у Київській - 4714 осіб, у Подільській - 1902 родин (з них 511 мали російське підданство).

14 березня 1892 р. Олександр III у Гатчині підписав указ сенату, в якому заборонив усім іноземцям, в тому числі й тим, які обрали російське підданство, оселятись у Волинській губернії на вільних землях. Цар надав волинському губернаторові право в адміністративному порядку висилати осіб, які оселились у межах означеної території після оприлюднення указу. Виняток було зроблено лише для тих, хто прийняв православ'я [6].

Ця заборона стосувалася й тих переселенців, які проживали у інших губерніях, оскільки в пункті 2 нових правил було зафіксовано право володіти і користуватися земельними ділянками лише до закінчення орендних контрактів. Ці закони докорінно змінили становище іноземців в Україні. Саме тому останні починали шукати можливості для еміграції за межі Росії. Але ці 
прагнення були паралізовані чинними в імперії законами щодо виїзду на постійне місце проживання за кордон і набуття іншого громадянства. Наприклад, німці-колоністи примусово повертались $з$ прикордонних перехідних пунктів до попереднього місця проживання.

Отже, національний чинник у правовому регулюванні суспільних відносин у XVIII-XIX ст. підпорядковувався перш за все офіційній колоніальній політиці «збирання земель» та утримання підкорених народів і національних меншин під політичним контролем. Значна кількість нормативно-правових актів була спрямована на уніфікацію духовно-культурного життя та асиміляцію підданих, котрі не належали до етнічних великоросів. Це призвело до зниження загальноосвітнього та культурного рівня населення так званих «окраїн», загальмувало їхній політичний, економічний та соціальний розвиток. В основі колонізаційної політики Російської імперії цього періоду можна простежити чітко сформовані інтереси щодо іммігрантів. Вони визначалися необхідністю заселення нових земель, потребою створення соціальної опори імперської влади та формування політично лояльних соціальних груп.

У зв'язку з необхідністю контролю за рухом населення, яке належало до різних етнічних груп і під впливом іноземних країн правлячі верстви Росії прийшли до усвідомлення потреби детального обліку населення загалом і його етнічного складу зокрема. Особливо цікавим 3 погляду встановлення нової фіскальної системи у пореформений період були багатонаціональні міста України.

Іншою передумовою проведення перепису й фіксації етнічної складової населення став активний розвиток залізничного та промислового будівництва. Упродовж 1865-1875 рр. в Україні стрімкими темпами зростала мережа залізниць. Вони поєднали Москву з Одесою й Севастополем i проходили через Київ. Це сприяло активному зростанню існуючих міст та появі нових. Рівень ï економічного розвитку був безпосереднім стимулятором етносоціальних процесів. Великі міста - центри виробництва і торгівлі, адміністративного, суспільного і культурного життя стали осередками активних міжетнічних контактів і взаємодії різних етнічних груп. Це сприяло створенню надзвичайно динамічного етнічного середовища.

Друга половина XIX ст. стала періодом міграції до міст українського селянства й росіян центральних і північних губерній. Скасування кріпацтва вивільнило необхідні для міста робочі руки, яких воно потребувало у зв'язку з промисловим переворотом. Сприяло переселенню й те, що у пореформений період у селянські общини в Україні було об'єднано лише 30 \% селян Лівобережжя й $15 \%$ Правобережжя. Іншим фактором змін етнічного складу міст України стала запроваджена 1874 р. загальна військова повинність. До міських військових гарнізонів потрапляли селяни з Білорусії, України, Росії.

Зростаюча мобільність суспільних процесів, потреба у відповідній базі даних для забезпечення адекватних методів державного управління, а також приклад західних держав спонукали Російську імперію змінити систему обліку населення й запровадити загальнодержавні переписи. Скасування кріпацтва, проведення призову до армії в нових умовах, здійснення ліберальних реформ, зростання промислового розвитку, будівництво залізниць викликало потребу в уточненні інформації щодо кількісного та якісного складу населення для вироблення адекватної внутрішньої політики й адміністративно-управлінської системи. Зміцнення фінансового становища країни, розвиток середньої та вищої освіти - все це сприяло створенню відповідної кадрової, освітньої і матеріально-технічної бази для реалізації завдань перепису населення.

До його проведення Російська імперія готувалася упродовж майже всього пореформеного періоду. Організація перепису потребувала не лише значних фінансових витрат, але й досягнення країною певного економічного, соціального та освітнього рівня. 3 іншого боку, величезні простори держави, недостатність комунікацій між регіонами, багатонаціональний склад населення, наявність населення, яке жило у кочовий спосіб, ускладнювало реалізацію завдань перепису.

Питання про перепис неодноразово порушувалося, починаючи 31858 р., але повсякчас відкладалося у зв'язку з браком коштів. Його пропонували провести російські статистики П. Кеппен, А. Бушен, Ю. Янсон. Але особливу роль відіграв відомий російський географ і статистик П. Семенов. Він був директором Центрального статистичного комітету Міністерства внутрішніх справ упродовж 1864-1875 рр., а згодом Головою Статистичної ради (1875-1897). Під його керівництвом було розроблено проект Положення про перепис [1]. Цей документ розглядався у 1870 р. на першому загальноросійському статистичному з'їзді, скликаному за ініціативою П. Семенова. У 1872 р. у Санкт-Петербурзі відбулася VIII сесія Міжнародного статистичного конгресу [13, 45]. Статистики з різних країн обговорили програму перепису, запропоновану російським вченим і схвалили іiі. Серед багатьох наукових рекомендацій були окреслені й критерії визначення національної приналежності. Було запропоновано покладатися на самосвідомість опитуваних і жодним не тиснути на них. Але, як засвідчила практика проведення перепису, не самосвідомість, а саме рідна мова стала основним критерієм під час проведення загальноросійського перепису населення, що 
спричинило певні недоліки застосованої владою програми обліку населення.

Пропозиції російських статистиків не знайшли підтримки держави. Пройшло понад 30 років, перш ніж уряд знайшов можливості для його вирішення. Роботи з проведення перепису потребували значних витрат, а також залучення великої кількості людей. Упродовж 60-80-х років XIX ст. імперія не мала таких можливостей. Труднощі, що виникли, були пов'язані із війною 1877-1878 рр., на яку держава витратила значні ресурси. Так, за Сан-Стефанською мирною угодою 1878 р. збитки Росії становили 1,4 млрд рублів. Упродовж 1877-1881 рр. держава витратила на ведення війни 1113,5 млн рублів. Зовнішній борг Російської імперії на 1 січня 1881 р. становив 6 млрд рублів [28, 475, 606]. Лише у 1893 р. уряд визнав необхідність проведення загальноросійського перепису населення.

Таким чином, потреби управління надзвичайно строкатим за соціальними, етнічними, культурно-господарськими характеристиками складом населення, а також динаміка соціальних змін у пореформену добу змусили російський уряд провести перепис населення. Одним із його складників став облік етнічного складу населення насамперед у містах. Чіткі статистичні відомості, які були б отримані державою під час перепису, дозволили б ефективно вирішити питання встановлення політичного контролю над поліетнічною Наддніпрянською Україною, придушити національні рухи, а саме український і польський, реалізувати програму асиміляції національних окраїн до імперського простору.

\section{ДЖЕРЕЛА}

1. Ананьева О. Первая всеобщая перепись в России [Электронный ресурс] / О. Ананьева. - Режим доступа : http://schools.keldysh.ru

2. Багалій Д.І. Заселення Південної України і перші початки їі культурного розвитку / Д.І. Багалій. Харків : Союз, 1920. - 110 с.

3. Бовуа Д. Битва за землю в Україні 1863-1914 рр.: поляки в соціоетнічних конфліктах / Д. Бовуа. - К. : Критика, 1998. - 410 с.

4. Буравський О.А. Поляки Волині у другій половині XIX - на початку XX ст. / О.А. Буравський. Житомир : Вид-во ЖДУ, 2004. - 168 с. ; іл.

5. Высочайшее повеление, объявленное Министром Внутренних Дел «О подчинении иноверческих школ Юго-Западного края ведомству министерства Народного Просвещения» // ПСЗРИ. Собрание Третье. 1881-1913. - T. VII (1887). — № 4759 от 8 октября 1887 г. - СПб. : Типография II Отд. Собственной Е.И.В. Канцелярии, 1889. - С. 432.

6. Высочайше утвержденное положение Кабинета министров «О принятии в русское подданство, переселившихся в Волынскую губернию Австрийских выходцев Чехов, с предоставлением им прав и преимуществ, установленных для водворяющихся в России иностранных рабочих» // ПСЗРИ. Собрание Второе. 1825-1881. - Т. XLV (1870). - Ч. 2. - № 48551 от 10 июля 1870 г. - СПб. : Типография II Отд. Собственной Е.И.В. Канцелярии, 1874. - С. 20-21.

7. Высочайше утвержденное положение Комитета Министров «О приведение в действие временных правил о евреях» // ПСЗРИ. Собрание Третье. 1881-1913. - Т. II (1882). — № 834 от 3 мая 1886 г. - СПб. : Типография II Отд. Собственной Е.И.В. Канцелярии, 1830 - С. 181; див. також.: Общий обзор деятельности Министерства внутренних дел за время царствования императора Александра III. - Санкт-Петербург, 1901. - Ч. IV - С. 193.

8. Высочайшее утвержденное положение Комитета Министров «Об установлении особых правил водворения в Волынской губернии лиц не русского происхождения» // ПСЗРИ. Собрание Третье. 1881-1913 - T. XII (1892). - № 8420 от 14 марта 1892 г. - СПб. : Типография II Отд. Собственной Е.И.В. Канцелярии, 1895 - С. 165.

9. Высочайше утвержденное положение «О устройстве Евреев» // ПСЗРИ. Собрание Первое. С 1649 по 12 Декабря 1825 года. - T. XXVIII (1804-1805). — № 21547 от 9 декабря 1804 г. — СПб. : Типография II Отд. Собственной Е.И.В. Канцелярии, 1830. - С. 731-737.

10. Высочайше утвержденное положение о евреях, опубликованное 31 мая // ПСЗРИ. Собрание Второе. 1825-1888 - Т. X (1835). — Ч. 1. - № 8054 от 31 мая 1836 г. - СПб. : Типография II Отд. Собственной Е.И.В. Канцелярии, 1836. - С. 308-323.

11. Высочайше утвержденное 19 декабря 1844 года положение «О подчинении Евреев в городах и уездах общему управлению, с уничтожением Еврейских кагалов» // ПСЗРИ. Собрание второе. Том XIX. 1844. - Отделение первое. - СПб. : Типография II Отд. Собственной Е.И.В. Канцелярии, 1845. - C. $887-890$. 
12. Гольдштейн М.И. Очерки истории евреев Полтавщины (1804-1920 гг.) / М.И. Гольдштейн. Полтава : Скайтэк. - 1998. - 67 с.

13. Григорянц М. Первый демографический автопортрет России / М. Григорянц // Мир России. 1997. — № 4. - С. 45-48.

14. Громачевський С.Г. Ограничительные законы по землевладению в Западном крае с историческим обзором их, законодательными мотивами и разъяснениями / С.Г. Громачевський. - СПб., 1904. - $176 \mathrm{c}$.

15. Завьялов Ф.Н. К 110-летию первой переписи населения России / Ф.Н. Завьялов // Ярославский педагогический вестник. - 2009. - № 2. - С. 214-219.

16. Именной данный Николаевскому и Севастопольскому Военному Губернатору указ «О воспрещении неслужащим Евреям иметь постоянное пребывание в городах Севастополь и Николаев» // ПСЗРИ. Собрание Второе. 1825-1881. - T. IV (1829). — № 3286 от 20 ноября 1829 г. — СПб. : Типография II Отд. Собственной Е.И.В. Канцелярии, 1830. - С. 790-791.

17. Именной данный Сенату указ «О взымании с евреев купцов 1-й гильдии за торговые свидетельства по 1800 р.» // ПСЗРИ. Собрание Второе. 1825-1888. — Т. Х (1835). — Ч. 1. — № 8193 от 31 мая 1836 г. - СПб. : Типография II Отд. Собственной Е.И.В. Канцелярии, 1836. - С. 671.

18. Именной данный Сенату указ «Об установлении особых правил относительно приобретения иностранцами в собственность или в срочное владение и пользование недвижимых имуществ в некоторых губерниях западной полосы России» // ПСЗРИ. Собрание Третье. 1881-1913. - T. VII (1887). — № 4286 от 14 марта 1887 г. - СПб. : Типография II Отд. Собственной Е.И.В. Канцелярии, 1889. - С. $101-102$.

19. Именной данный Сенату указ «Об установлении правил относительно приобретения в собственность, залога и арендования в девяти Западных губерниях земельных имуществ, вне городов и местечек расположенных» // ПСЗРИ. Собрание Третье. 1881-1913. - Т. IV (1884). № 2653 от 27 декабря 1884 г. - СПб. : Типография II Отд. Собственной Е.И.В. Канцелярии, 1887. C. 602-604.

20. Кадомцев Б.П. Профессиональный и социальный состав населения европейской России по данным переписи 1897 года: критико-статистический этюд / Б.П. Кадомцев. - СПб.: Тип. Шредера, 1909. - 27 c.

21. Каппелер А. Мазепинцы, малороссы, хохлы: украинцы в этнической иерархии Российской империи [Электронный ресурс] / А. Каппелер // Россия - Украина: история взаимоотношений / отв. ред. Миллер А.И. и др. - М. : Яз. рус. культуры, 1997. - Режим доступа : http://litopys.narod.ru/ vzaimo/vz11.htm

22. Кеппен П.И. Об этнографической карте Европейской России. / П. И. Кеппен. - СПб., 1852. - 40 с. 23. Ковба Ж.Н. Чешская эмиграция на Украине во вт. пол. XIX - начале XX ст. : дис. ... канд. істор. наук. : 07.00.01 / Ж.Н. Ковба. — Львів, 1974. - 226 с.

24. Котельников А. История производства и разработки всеобщей переписи населения 28-го января 1897 г. / А. Котельников. - СПб. : Издательство книжного магазина «Наша жизнь», 1909. — 124 с.

25. Крыжановский Е. Чехи на Волыни / Е. Крыжановский. - СПб. : Синодальная типография, 1887. - 160 c.

26. Лісевич I.T. У затінку двоглавого орла (польська національна меншина на Наддніпрянській Україні в др. пол. ХIX - на початку XX ст. / І.Т. Лісевич. - К., 1993. — 87 с.

27. Малий В.В. Українці Поділля наприкінці XIX ст. (статистично-демографічний аналіз) / B.В. Малий // Наукові праці Кам’янець-Подільського національного університету ім. I. Огієнка: Історичні науки. - Кам'янець-Подільський : [s. n.], 2009. - Т. 19. - С. 392-398.

28. Мигулин П.П. Русский государственный кредит (1769-1899): опыт историко-критического обзора / П.П. Мигулин. - Харьков, 1899. - Т. 1. - 606 с.

29. Мокроусова О.Н. Євреї міста Києва / О. Мокроусова, Н. Гамоля // Контракти. — 2005. — № 1. 17 ciч.

30. Миллер А.И. «Украинский вопрос» в политике властей и русском общественном мнении (вторая половина ХІХ века) / А.И. Миллер. - СПб. : Алетейя. - 2000. - 267 с.

31. Общий обзор деятельности Министерства внутренних дел за время царствования императора Александра III. - Санкт-Петербург, 1901. - [4], ч. IV. — 347 с.

32. Павловский И.Ф. Статистика еврейского населения в Полтавской губернии со времени ее учреждения и о черте оседлости / И.Ф. Павловский. - Полтава : Тип. 3.И. Маркевича, 1908. - 14 с. 33. Пилипенко О. Трудова імміграція в Україну і політика Російської імперії щодо переселенців у другій половині ХІХ ст. / О. Пилипенко // Людина і політика. - 1999. - № 3. - С. 19-23.

34. Погребінська I.M. Правове та економічне становище євреїв в Україні (кін. XIX поч. XX ст.) / I.М. Погребінська // Український історичний журнал. - 1996. — № 4 - С. 124-132.

35. Риттих А.Ф. Атлас народонаселения Западно-русского края по исповеданиям / А.Ф. Риттих. СПб., 1863. -48 c. 
36. Сінкевич І.Ю. Етнічна ситуація в Херсонській губернії в дослідженнях херсонських статистиків (друга половина XIX ст.) / І.Ю. Сінкевич // Заселення Півдня України: проблеми національного та культурного розвитку. - Херсон, 1997. - Ч. 2. - С. 153-155.

37. Соловьева А.M. Железнодорожный транспорт России во второй половине XIX в. / А.М. Соловьева. - М. : Наука, 1975. - С. 63-112.

38. Толмачев И.Н. Юго-Западный край: статистическое обозрение, Восточное Полесье / И.Н. Толмачев. - К. : Тип. Штаба Киевского Военного Округа, 1897. — Т. 1. - 480 с.

39. Хонигсман Я.С. Евреи Украины: краткий исторический очерк ; под ред. Ф.Я. Горовского / Я.С. Хонигсман, А.Я. Найман. - К., 1992. - 156 с.

40. ЦДІАУК - Ф. 442. - Оп. 618. - Спр. 261. - Арк. 113-114. Також див.: Пилипенко О. Трудова імміграція в Україну і політика Російської імперії щодо переселенців у другій половині XIX ст. / О. Пилипенко // Людина і політика. - 1999. - № 3. - С. 19-23.

41. Чирков О. Стан етнічної будови людності України на межі XIX й XX століть (за статистичними даними) / О. Чирков // Українознавство. - 2009. — № 3. - С. 265-271.

42. Чубинський П.П. Обзор данных о населении города Києва по однодневной переписи произведенной 2 марта 1874 г. / П.П. Чубинський // Реферат, прочитанный в годичном собрании ЮгоЗападного Отдела 23 марта 1875 г. - К. : Тип. М.П. Фрица, 1875. - 32 с.

43. Шмидт А. Материалы для географии и статистики России. Херсонская губернія : в 2-х частях / А. Шмидт. - СПб. : Тип. Калиновского, 1863. - Ч. 2. - 874 с.

44. Щербак Н.О. Національна політика царату у Правобережній Україні в кінці XIX — на початку XX ст. (За матеріалами звітів місцевих державних установ) : дис. ... канд. іст. наук. : 07.00.02 / Н.О. Щербак. - К., 1995. - 163 с.

45. Ярошевич А. Малороссы по переписи 1897 г. / А. Ярошевич // Киевская старина. — 1905. — T. LXXXIX. - № 6. - C. 411-423.

\section{REFERENCES}

1. Ananyeva O. Pervaya vseobshchaya perepis v Rossii [Eletronnyi resurs] / O. Ananyeva. - Rezhim dostupa : http://schools.keldysh.ru

2. Bahaliy D.I. Zaselennia Pivdennoi Ukrainy i pershi pochatki ii kulturnoho rozvytku / D.I. Bahaliy/ Kharkiv : Soiuz, 1920. - $110 \mathrm{~s}$.

3. Bovua D. Bytva za zemliu v Ukraini 1863-1914 rr.: Poliaky v sotsioetnichnyh konfliktakh / D. Bovua. K. : Krytyka, 1998. - 410 s.

4. Buravskyi O.A. Poliaky Volyni u druhiy polovyni XIX - na pochatku XX st. / O.A. Buravskyi. Zhytomyr : Vid-vo ZhDU, 2004. - 168 s. ; il.

5. Vysochaysheye poveleniye obyavlennoye Ministrom Vnutrennikh Del «O podchinenii inovercheskikh shkol Yugo-Zapadnogo kraya vedomstvu ministerstva Narodnogo Prosveshcheniya» // PSZRI. Sobraniye Tretye. 1881-1913. - T. VII (1887). - № 4759 ot 8 oktyabrya 1887 g. - SPb. : Tipografiya II Otd. Sobstvennoy E.I.V. Kantselyarii, 1889 - S. 432.

6. Vyisochaysheye utverzhdennoye polozheniye Kabineta ministrov «O priniatii v russkoye poddanstvo, pereselivshykhsya v Volynskuyu guberniyu Avstriyskikh vyhodtsev Chekhov, s predostavleniyem im prav i preimuschestv, ustanovlennykh dlya vodvoryayushchihsya v Rossii inostrannykh rabochikh» // PSZRI. Sobraniye Vtoroye. 1825-1881. - T. XLV (1870). - Ch. 2 - № 48551 ot 10 iyulya 1870 g. - SPb. : Tipografiya II Otd. Sobstvennoy E.I.V. Kantselyarii, 1874. - S. 20-21.

7. Vysochayshe upverzhdennoye polozheniye Komiteta Ministrov «O privedeniye v deystviye vremennykh pravil o yevreyakh» // PSZRI. Sobranie Tretye. 1881-1913. — T. II (1882). — № 834 ot 3 maya 1886 g. — SPb. : Tipografiya II Otd. Sobstvennoy E.I.V. Kantselyarii, 1830 - S. 181; div. takozh.: Obshchiy obzor deyatelnosti Ministerstva vnutrennikh del za vremya tsarstvovaniya imperatora Aleksandra III. - SanktPeterburg, 1901. - Ch. IV - S. 193.

8. Vysochaysheye utverzhdennoye polozheniye Komiteta Ministrov «Ob ustanovlenii osobykh pravil vodvoreniya v Volynskoy gubernii lits ne russkogo proiskhozhdeniya» // PSZRI. Sobranie Tretye. 18811913. - T. XII (1892). — № 8420 ot 14 marta 1892 g. — SPb. : Tipografiya II Otd. Sobstvennoy E.I.V. Kantselyarii, 1895 - S. 165.

9. Vysochayshe utverzhdennoye polozheniye «O ustroystve Yevreyev»// PSZRI. Sobranie Pervoe. S 1649 po 12 Dekabrya 1825 goda. - T. XXVIII (1804-1805). — № 21547 ot 9 dekabrya 1804 g. — SPb. : Tipografiya II Otd. Sobstvennoy E.I.V. Kantselyarii, 1830. - S. 731-737

10. Vyisochayshe utverzhdennoe polozhenie o evreyah opublikovannoye 31 maya // PSZRI. Sobranie Vtoroye. 1825-1888. - T. X (1835). - Ch. 1. — № 8054 ot 31 maya 1836 g. - SPb. : Tipografiya II Otd. Sobstvennoy E.I.V. Kantselyarii, 1836. - S. 308-323. 
11. Vysochayshe utverzhdennoye 19 dekabrya 1844 goda polozheniye «O podchinenii Yevreyev v gorodakh i uyezdakh obshchemy upravleniyu, s unichtozheniyem Yevreyskikh kagalov» // PSZRI. Sobraniye vtoroye. - Tom XIX. 1844. - Otdeleniye pervoye. - SPb. : Tipografiya II Otd. Sobstvennoy E.I.V. Kantselyarii, 1845. - S. 887-890.

12. Goldshteyn M.I. Ocherki istorii yevreyev Poltavshchiny (1804-1920 gg.) / M.I. Goldshteyn. — Poltava : Skaytek. - 1998. - 67 s.

13. Grigoryants M. Pervyi demograficheskiy avtoportret Rossii / M. Grigoryants // Mir Rossii. — 1997. — № 4. - S. 45-48.

14. Gromachevskiy S.G. Ogranichitelnyye zakony po zemlevladeniyu v Zapadnom kraye s istoricheskim obzorom ikh, zakonodatelnymi motivami i razyasneniyami / S.G. Gromachevskiy. — SPb., 1904. — 176 s. 15. Zavyalov F.N. K 110-letiyu pervoy perepisi naseleniya Rossii / F.N. Zavyalov // Yaroslavskiy pedagogicheskiy vestnik. - 2009. - № 2. - S. 214-219.

16. Imennoy dannyi Nikolaevskomu i Sevastopolskomu Voyennomu Gubernatoru ukaz «O vospreshchenii nesluzhashchim yevreyam imet postoyannoye prebyvanie v gorodah Sevastopol i Nikolayev» // PSZRI. Sobranie Vtoroye. 1825-1881. - T. IV (1829). — № 3286 ot 20 noyabrya 1829 g. - SPb. : Tipografiya II Otd. Sobstvennoy E.I.V. Kantselyarii, 1830. - S. 790-791.

17. Imennoy dannyi Senatu ukaz «O vzymanii s yevreyev kuptsov 1-i gildii za torgovyye svidetelstva po 1800 r.» // PSZRI. Sobraniye Vtoroye. 1825-1888. — T. X (1835). — Ch. 1. — № 8193 ot 31 maya 1836 g. SPb. : Tipografiya II Otd. Sobstvennoy E.I.V. Kantselyarii, 1836 - S. 671.

18. Imennoy dannyi Senatu ukaz «Ob ustanovlenii osobykh pravil otnositelno priobreteniya inostrantsami v sobstvennost ili v srochnoe vladenie i polzovanie nedvizhimyih imuschestv v nekotorykh guberniyakh zapadnoi polosy Rossii»// PSZRI. Sobranie Trete. 1881-1913. — T. VII (1887). — № 4286 ot 14 marta 1887 g. — SPb. : Tipografiya II Otd. Sobstvennoy E.I.V. Kantselyarii, 1889. - S. 101-102.

19. Imennoy dannyi Senatu ukaz «Ob ustanovlenii pravil otnositelno priobreteniya v sobstvennost, zaloga i arendovaniya v devyati Zapadnykh guberniyakh zemelnykh imuschestv, vne gorodov i mestechek raspolozhennykh»// PSZRI. Sobranie Tretye. 1881-1913. - T. IV (1884). — № 2653 ot 27 dekabrya 1884 g. - SPb. : Tipografiya II Otd. Sobstvennoy E.I.V. Kantselyarii, 1887. - S. 602-604.

20. Kadomtsev B.P. Professionalnyi i sotsialnyi sostav naseleniya yevropeyskoy Rossii po dannym perepisi 1897 goda: Kritiko-statisticheskiy etyud; Izd. S.-Peterb. politehn. in-ta / B.P. Kadomtsev. — SPb. : Tip. Shredera, 1909. - 27 s.

21. Kappeler A. Mazepintsy, malorossy, hohly: ukraintsy v etnicheskoy ierarkhii Rossiyskoy imperii [Elektronnyi resurs] / A. Kappeler // Rossiya - Ukraina: istoriya vzaimootnosheniy / otv. red. Miller A.I. i dr. - M. : Yaz. rus. kultury, 1997. - Rezhim dostupa : http://litopys.narod.ru/vzaimo/vz11.htm

22. Keppen P.I. Ob etnograficheskoy karte Yevropeyskoy Rossii / P.I. Keppen. — SPb., 1852. — 40 s.

23. Kovba Zh.N. Cheshskaya emmigratsiya na Ukraine vo vt. pol. XIX — nachale XX st. : dis. ... kand. ist. nauk / Zh.N. Kovba - Lviv, 1974. - 226 s.

24. Kotelnikov A. Istoriya proizvodstva i razrabotki vseobshchey perepisi naseleniya 28-go yanvarya 1897 g. / A. Kotelnikov. — SPb. : Izdatelstvo knizhnogo magazina «Nasha zhizn». — 1909 - 124 s.

25. Kryzhanovskiy Ye. Chekhi na Volyni / Ye. Kryizhanovskiy. — SPb. : Sinodalnaya tipografiya, 1887. $160 \mathrm{~s}$.

26. Lisevich I.T. U zatinku dvohlavoho orla (polska natsionalna menshina na Naddnipryanskiy Ukrayini v dr. pol. XIX na pochatku XX st. / I.T. Lisevich. - K., 1993. - 87 s.

27. Malyi V.V. Ukrayintsi Podillya naprykintsi XIX st. (statystychno-demohrafIchniy analiz) / V.V. Malyi // Naukovi pratsi Kamianets-Podilskoho natsionalnoho universitetu im. I. Ohiienka: Istorichni nauky. Kam'yanets-Podilskiy : [s. n.], 2009. - T. 19. - S. 392-398.

28. Migulin P.P. Russkiy gosudarstvennyi kredit (1769-899): Opyt istoriko-kriticheskogo obzora / P.P. Migulin. - Kharkov, 1899. - T. 1. - 606 c.

29. Mokrousova O. Yevrei mista Kyieva / O. Mokrousova, N. Hamolia // Ukrainskyi dilovyi tyzhnevyk «Kontrakty». - 2005. - № 1. - 17 sich.

30. Miller A.I. «Ukrainskiy vopros» v politike vlastey i russkom obschestvennom mnenii (vtoraya polovina XIX veka). - SPb. : Aleteyya. - 2000. - 267 s.

31. Obschiy obzor deyatelnosti Ministerstva vnutrennih del za vremya tsarstvovaniya imperatora Aleksandra III. — Sankt-Peterburg, 1901. - [4], ch. IV. — 347 s.

32. Pavlovskiy I.F. Statistika yevreyskogo naseleniya v Poltavskoy gubernii so vremeni eyo uchrezhdeniya i o cherte osedlosti / I.F. Pavlovskiy. - Poltava : Tip. Z.I. Markevicha, 1908. - 14 s.

33. Pylypenko O. Trudova Immigratsiia v Ukrainu i politika Rosiyskoi Imperii schodo pereselentsiv u drugiy polovini XIX st. / O. Pylypenko // Liudina i polityka. - 1999. - № 3. - S. 19-23.

34. Pohrebinska I.M. Pravove ta ekonomichne stanovyshche Yevreiv v Ukraini (kin. XIX — poch. XX st.) / I.M. Pogrebinska // UIZh. — K. : 1996. — № 4 - S. 124-132.

35. Rittikh A.F. Atlas narodonaseleniya Zapadno-russkogo kraya po ispovedaniyam / A.F. Rittih. - SPb., 1863. $-48 \mathrm{~s}$. 
36. Sinkevich I.Yu. Etnichna sytuatsiia v Khersonskii hubernii v doslidzhenniakh khersonskyh statystykiv (druha polovyna XIX st.) / I.Yu. Sinkevych // Zaselennia Pivdnia Ukrainy: problemy natsionalnoho ta kulturnoho rozvytku: Nauk. dop. Mizhnarod. naukovo-metod. konf. - Ch. 2. - Kherson, 1997. — S. $153-155$.

37. Solovyova A.M. Zheleznodorozhnyi transport Rossii vo vtoroy polovine XIX v. / A.M. Solovyova. M. : Nauka, 1975. - S. 63-112.

38. Tolmachev I.N. Yugo-Zapadnyi kray. Statisticheskoye obozreniye. Vostochnoye Polesye. I I.N. Tolmachev. - K. : Tip. Shtaba Kievskogo Voyennogo Okruga. 1897. - T. 1. - 480 s.

39. Honigsman Ya.S. Yevrei Ukrainy: Kratkiy istoricheskiy ocherk ; pod red. F.Ya. Gorovskogo. I Ya.S. Honigsman, A.Ya Nayman. - K., 1992. - 156 s..

40. TsDIAUK - F. 442. - Op. 618. - Spr. 261. - Ark. 113-114. Takozh dyv.: Pylypenko O. Trudova Immigratsiia v Ukrainu i polityka Rosiiskoi Imperii shchodo pereselentsiv u druhii polovyni XIX st. / O. Pylypenko // Liudyna i politika. - 1999. - № 3. - S. 19-23.

41. Chirkov O. Stan etnichnoi budovy liudnosti Ukrainy na mezhi XIX i XX stolit (za statystychnymy danymy) / O. Chirkov // Ukrainoznavstvo. — 2009. — № 3. - S. 265-271..

42. Chubinskiy P.P. Obzor dannykh o naselenii goroda Kieva po odnodnevnoy perepisi proizvedennoy 2 marta 1874 g. / P.P. Chubinskiy // Referat, prochitannyiy v godichnom sobranii Yugo-Zapadnogo Otdela 23 marta 1875 g. - K. : Tip. M.P. Fritsa, 1875. - 32 s.

43. Shmidt A. Materialy dlya geografii i statistiki Rossii. Khersonskaya guberniya. V 2-h chastyah. I A. Shmidt - SPb. : Tip. Kalinovskogo, 1863. - Ch. 2. - 874 s.

44. Shcherbak N.O. Natsionalna polityka tsaratu u Pravoberezhniy Ukraini v kintsi XIX — na pochatku XX st. (Za materialamy zvitiv mistsevykh derzhavnykh ustanov) : dis. ... kand. istor. nauk : 07.00.02. K., 1995. - $163 \mathrm{~s}$.

45. Yaroshevich A. Malorossy po perepisi 1897 g. / A. Yaroshevich // Kievskaya starina. — 1905. — T. LXXXIX 1905. — № 6. - S. 411-423.

\section{Олег Иванюк}

\section{ПРЕДПОСЫЛКИ ПРОВЕДЕНИЯ ВСЕОБЩЕЙ ПЕРЕПИСИ 1897 г. В НАДДНЕПРЯНСКОЙ УКРАИНЕ И НЕОБХОДИМОСТЬ В ОПРЕДЕЛЕНИИ ЭТНИЧЕСКОГО СОСТАВА НАСЕЛЕНИЯ}

В статье осуществлен анализ государственной этнополитики Российской империи в XIX в. Определено, что ее главным стержнем стала лояльность подданных по отношению к государству и правящей династии. Рассмотрены основные предпосылки подготовки и проведения общероссийской переписи населения 1897 г. в контексте решения проблемы о необходимости определения этнического состава жителей империи. Выяснено, что на протяжении XIX в. с целью упорядочения или ограничения прав начиональных меньшинств был издан ряд законодательных актов, что в свою очередь привело к значительным перемещениям населения и превращению городов Украины в многонациональные административные центры. В связи с необходимостью контроля за движением населения, которое принадлежало к различным этническим группам, и под влиянием иностранных государств власть пришла к осознанию необходимости детального учета населения в челом и его этнического состава в частности.

Ключевые слова: перепись, этнический состав, национальная политика, этническая группа, национальное меньшинство, иностранные переселенцы.

\section{Oleg Ivanyuk \\ PRECONDITIONS OF THE OVERALL CENSUS IN DNIEPER UKRAINE IN 1897 AND REQUIREMENTS FOR DETERMINATION OF ETHNIC COMPOSITION OF POPULATION}

The article examines the basic preconditions of preparation and conduct of the All-Russian census of 1897 in the context of solving the problem of the requirements to determine the ethnic composition of the inhabitants of the empire. The analysis of the state ethnic policy of the Russian Empire in the $19^{\text {th }}$ century is made, 
and it is determined that the main pillar was the loyalty of citizens towards the state and the ruling dynasty. The study also found that during the $19^{\text {th }}$ century, in order to regulate or limit the rights of national minorities, a number of legislative acts were published, which in turn led to significant population movements and the transformation of cities in Ukraine to multinational administrative centers. In connection with the need to control the movement of the population, which belonged to different ethnic groups, and under the influence of foreign countries the authority realized the need for a detailed account of the whole population and its ethnic composition, in particular.

Key words: census, ethnicity, national policy, ethnic group, minority, foreign immigrants.

\section{Олександр Бонь}

\section{ДМИТРО ГОРДЄЄВ ТА ДІЯЛЬНІСТЬ ХАРКІВСЬКИХ МИСТЕЦТВОЗНАВЦІВ У 1920-1930-х РОКАХ}

У статті розглянуто життєвий илях і науковий доробок відомого харківського мистецтвознавия Дмитра Петровича Гордєєва у 1920-1930-х рр., визначено його місце та роль у розгортанні роботи багатьох мистецтвознавчих інституцій тогочасної столичі радянської України. Охарактеризовано коло мистецтвознавців, з якими співпрацював Д. Гордєєв. На прикладі діяльності вченого простежено механізми тиску тоталітарної держави на форми і тематику роботи харківських науковців. Також здійснено спробу дослідити трагічну долю харківської школи мистецтвознавців.

Ключові слова: Дмитро Гордєєв, мистецтвознавство, Харків, репресії, БАМЛАГ, В. Дубровський, В. Зуммер.

3 початком української революції 1917 р. у Київ та Харків на хвилі національного піднесення переїхали із Москви та Петрограда митці та мистецтвознавці, котрі посідали помітні позиції у столицях Росії. Це Георгій Нарбут, Борис Мозолевський, Павло Балицький, Павло Зайцев [5], Борис Крижановський, Микола Макаренко [17], Олекса Новицький [9], Сергій Трійницький, Степан Яремич та ін. Частина з них ніколи не жила в Україні, мала лише українське походження, як, наприклад, Олекса Новицький, але всі вони хотіли прислужитися українській культуpi. Цей феномен ще належить оцінити дослідникам. У зв'язку з цим значно посилився потенціал розвитку українського мистецтвознавства, охорони пам'яток, пам'яткознавства. Створення Всеукраїнської академії наук також дало значний поштовх пам'яткоохоронним, музеєзнавчим та мистецтвознавчим студіям.

У 1920-1930 рр. у радянській Україні існувало два найбільших центри мистецтвознавчих досліджень - Київ і Харків. У цих містах з дореволюційного часу склались українські мистецтвознавчі школи. Можна назвати імена київського мистецтвознавця Г. Павлуцького, Є. Рєдіна та Ф. Шміта, які плідно працювали у Харкові. Харківська та київська школи продовжили розвиватись у 1920-х роках у складних умовах погіршення матеріальної ситуації та встановлення ідеологічного диктату більшовицької влади. Серед плеяди харківських мистецтвознавців, учнів академіка Федора Івановича Шміта [6] помітне місце посів Дмитро Петрович Гордєєв, котрий розпочав свою наукову і творчу діяльність у передреволюційний період. Його постать, наукові й організаційні здобутки ще не оцінені належним чином.

Метою цього дослідження $є$ творчий внесок Дмитра Петровича Гордєєва у розвиток харківського мистецтвознавства.

Харківська мистецтвознавча школа 19201930-х років та пов'язані з нею наукові інституції вже були предметом зацікавлення таких дослідників, як В. Афанасьєв [1], С. Білокінь [2-4; 24], С. Побожій [22] та ін. Маємо й біографічні статті про постать Дмитра Гордєєва дослідниці Світлани Іваненко [11], а також про його пам'яткоохоронну діяльність С. Побожія [С. Побожий «В целях 